\title{
The MCS intensity distribution of the devastating 24 August 2016 earthquake in central Italy $\left(M_{W} 6.2\right)$
}

\author{
P. GALli ${ }^{1 *}$, E. PerOnACE ${ }^{2}$, F. BRAMERINi ${ }^{1}$, S. CASTENETto ${ }^{1}$, G. NAsO ${ }^{1}$, \\ F. CASSONE ${ }^{1}$, F. PALLONE ${ }^{1}$ \\ ${ }^{1}$ Dipartimento della Protezione Civile Nazionale, Rome Italy; \\ ${ }^{2}$ Consiglio Nazionale Delle Ricerche, Istituto di Geologia Ambientale e Geoingegneria, \\ Monterotondo Scalo, Rome, Italy

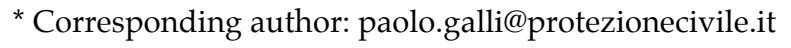

\begin{abstract}
Here we describe the macroseismic survey of the 24 August 2016 earthquake in central Italy $\left(M_{w} 6.2\right)$. By applying a revised version of the Mercalli-Cancani-Sieberg scale, we estimated the site intensity in more than 300 localities of Lazio, Abruzzi, Umbria and Marche regions, providing the Civil Protection with a quick and robust snapshot of the earthquake. The most severe effects are focused south of the instrumental epicenter, in the Amatrice intermountain basin, where intensity reached 10-11 MCS. Highest damage (area inside 9 MCS isoseismal) is focused in a NNW-SSE belt of the hangingwall of the causative faults, i.e. the southern segment of the Mount Vettore fault system and the northern segment of the Laga Mounts fault system, with northward damage propagation in the far-field. The intensity dataset allows to evaluate a $M_{w} 6.16 \pm 0.5$, which is very close to the instrumental magnitude, with a seismogenic box striking $N 161^{\circ}$, mimicking the geological active faults. Epicentral intensity is $I_{0} 10$ MCS, $I_{\text {мах }}$ 10-11. The elevated level of destruction is mainly due to the high vulnerability of buildings, mostly made by cobblestone masonry. Integrating the macroseismic information with the geological, geodetical and geophysical data it is possible to hypothesize a bidirectional rupture propagation (toward NNW and SSE) along the two different faults. It is also possible to attribute the $1639, M_{w} 6.0$ earthquake to the same source of the southern 2016 rupture (northernmost Laga Mounts faults).
\end{abstract}

\section{INTRODUCTION}

$\mathrm{I}$ n the night of 24 August 2016, at 3:36 local time, a unexpected earthquake hit the $\mathbf{1}_{\text {boundary area of four Regions of central It- }}$ aly (Lazio, Abruzzi, Marche and Umbria), rocking dozens of villages and burying under the rubbles hundreds of unaware, sleeping people. The instrumental hypocenter of the mainshock $\left(M_{L}\right.$ 6.0; $M w$ 6.2) was below the village of Accumoli, in the Tronto River valley
(Lazio Region), at a depth of approx. $8 \mathrm{~km}$, and it was shortly followed by a foreshock $\left(M_{W} 5.5\right)$ localized $10 \mathrm{~km}$ away, in the Norcia area (Umbria Region). Both these events were clearly felt in Rome, which is some $100 \mathrm{~km}$ far away, while the damage induced to the buildings estate extended up to $40 \mathrm{~km}$ to the north. Nonetheless, the earthquake devastated mainly the localities south of the epicenter, namely the small town of Amatrice and its villages (locally known as ville; 3000 inhabitants that increase 
tenfold during summer vacation). In October the sequence was still ongoing, with more than a dozen of $\mathrm{M}_{\mathrm{L}} \geq 4$ events scattered over $30 \mathrm{~km}$ long area in a NNW-SSE direction, besides almost 800, $\mathrm{M}_{\mathrm{L}} \geq 2.5$ [ISIDe 2016]. Almost all the focal mechanisms indicate NW-SE normal faulting, i.e. extension in a NE-SW direction [RCMT 2016].

Together with the nearby 2009 L'Aquila earthquake $\left(M_{W} 6.3\right)$, this is the strongest event that struck Italy since the 23 November 1980, $\mathrm{M}_{\mathrm{W}}$ 6.9 Irpinia earthquake (southern Apennine, $\mathrm{I}_{0}$ 10 MCS, almost 3000 casualties), with a death toll reaching 297, i.e., quite the same sorrowful amount of L'Aquila in 2009.

Starting from 1997 Umbria-Marche event $\left(\mathrm{M}_{\mathrm{W}}\right.$ 6.0 ), just a few hours after every strong earthquake in Italy, different teams of experts from the Dipartimento della Protezione Civile (DPC), and from the Istituto Nazionale di Geofisica e Vulcanologia (INGV) are dispatched to the epicentral area in order to launch the macroseismic survey. The main purpose of this survey is to provide the Civil Protection with 1) a univocal snapshot of the heavy damage distribution within a couple of days, and 2) a reliable distribution of damage in the far field within 20-30 days. Thus, before the end of September 2016, the teams from the DPC and INGV visited more than 300 localities within 76 municipalities of the Provinces of Rieti (Lazio), Perugia (Umbria), Teramo and L'Aquila (Abruzzi), Ascoli Piceno, Macerata and Fermo (Marche), and assessed the site intensity (Is) applying the Mercalli-CancaniSieberg (MCS) scale [Sieberg, 1930]. The evaluated intensity datapoints distribution (IDD; Appendix 1) later will merge into the Italian catalogue of historical earthquakes and the associated macroseismic intensities database (i.e., CPTI and DBMI. See Rovida et al. 2016, and Locati et al. 2016).

It is worth noting that during the editing of this paper other two $\mathrm{M}_{\mathrm{W}}>6$ earthquakes occurred approx. $20 \mathrm{~km}$ NNW with respect to the 24 August event (Mw 6.1, 26 October; $M_{W}$ 6.5,
30 October). The effects of these earthquakes are not discussed here. Suffice to say that almost all villages surveyed during AugustSeptember suffered further damage, making new field work necessary.

\section{HINTS ON THE LOCAL HISTORICAL SEISMICITY}

The Amatrice area - besides the strong effects suffered during the catastrophic 1703 JanuaryFebruary seismic sequence [Uria de Llanos 1703] (January 14, $\mathrm{M}_{\mathrm{W}} 6.9$ in the Norcia region; 2 February, $\mathrm{M}_{\mathrm{W}} 6.7$ in the L'Aquila region) was the source region of a seismic period occurred in the first half of the $17^{\text {th }}$ century. On 7 October 1639 a first event $\left(M_{W}\right.$ 6.0, Io 9-10 MCS) hit many ville of Amatrice (Cantone, Casale, Colle Basso, Collemoresco, Corva, Filetto, Forcelle, La Rocca, Roccasalli, San Giorgio, San Martino, Scai, and Torrita: all 9-10 MCS), causing severe damage in Amatrice itself (9 MCS) and Accumoli (8-9 MCS) [Tiberi 1639], beside being felt in the far towns of L'Aquila, Ascoli Piceno and Rieti, but not in Rome [Castelli et al. 2002]. In Norcia, a primary source $\left[A S C N ~ 17^{\text {th }}\right.$ cent.] suggests the absence of any important effect, differently from what happened in August 2016. On 28 April 1646 a second event hit again some of the villages around Amatrice, causing severe damage in Scai and Torrita (9 MCS), and also in Amatrice ( 8 MCS) [ASAQ $17^{\text {th }}$ cent.]. All together, these two earthquakes had a smaller impact than the 2016 one, as they were mainly focused in the Amatrice basin, without known effects to the north. Indeed, according to Castelli et al. [2002], the 1639 earthquake was caused by the rupture of a limited segment of the Laga Mounts fault, the total slip of which being instead consistent with $\mathrm{M}_{\mathrm{W}}>6.5$ earthquakes [Galadini and Galli 2003].

\section{BUILDING TYPOLOGY OF THE AREA}

As the earthquake struck a sector of the Apennine chain mainly characterized by extensive outcrops of turbiditic sandstones (Laga 
Flysch), these rocks constitute the preferred churches, castles and towers of the region. building material of all the houses, stables,
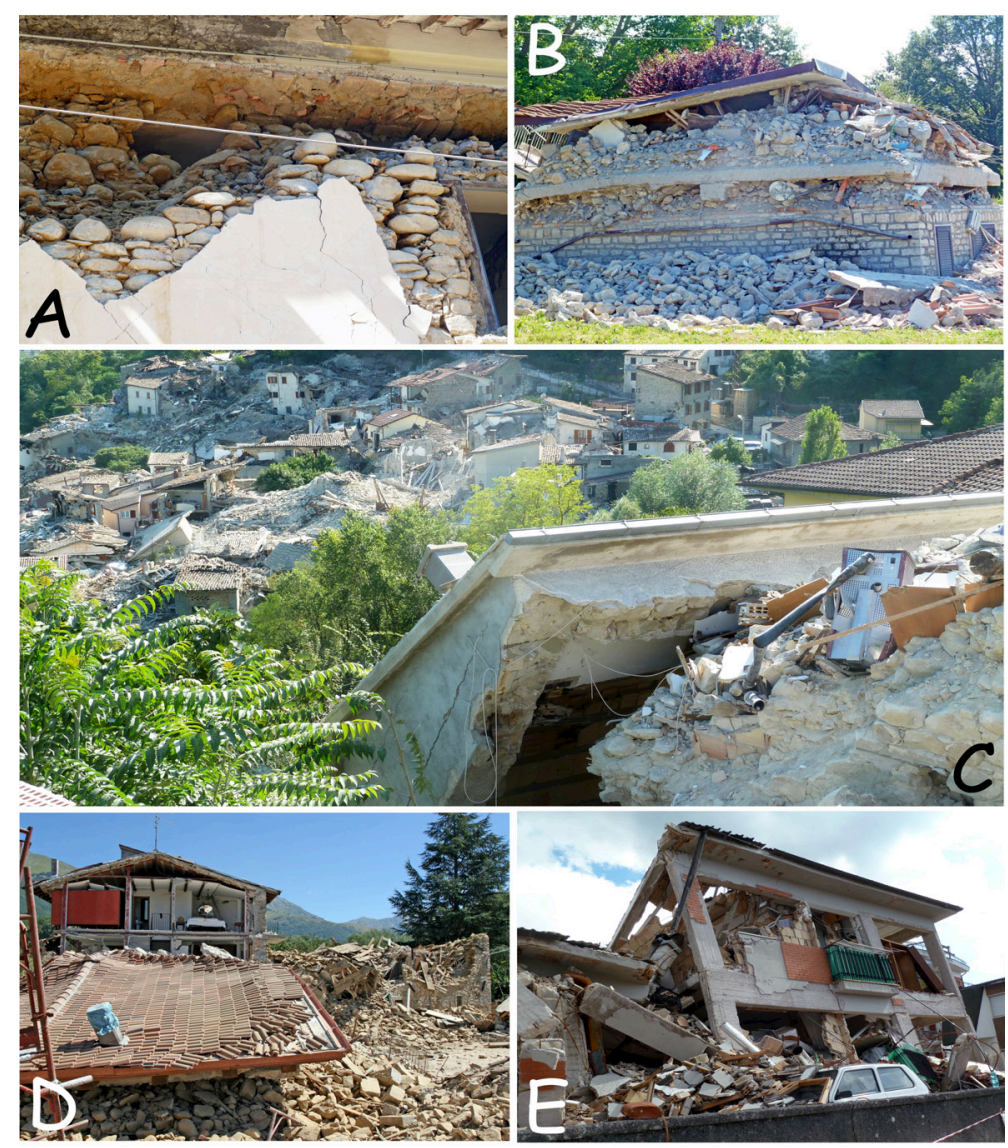

Figure 1. A, Rounded, fluvial cobbles masonry in Sommati (Amatrice). B, Collapse of a stone masonry building with RC ring beans (San Lorenzo e Flaviano, Amatrice). C, Crashed RC roof over a stone masonry house; in the background, view of the destroyed village of Pescara del Tronto (10-11 MCS). D, Collapse of stone masonry house in Petrana; behind, note the part of the same building added interiorly with a steel moment-resisting frame. E, Collapse of a RC building in Amatrice.

Indeed, buildings in the historical centers of all the villages are mostly made of rough stone masonry, often perfectly rounded fluvial cobbles and boulders (Fig. 1A), with squared angular stone and a very poor, dusty mortar. Secondarily, brick masonry (clay, hollow, and concrete bricks) is diffused in most villages, as well as Poroton ${ }^{\circledR}$ (i.e., load-bearing clay-brick with low void percentage). Many of this buildings date back to the 15th-early 20th century; some have been strengthened in the past decades with reinforced concrete ring beams, iron tie rods, while some were imprudently added with heavy concrete roof that behaved like a ram during the earth shaking, crushing the underlying masonry (Fig. 1B-D). Relatively few reinforced-concrete frame buildings and villas were built in the outskirts of Amatrice (1E), and in some other villages. At the same time, inside the historical centers of almost all the villages, 
derelict and stables houses coexist close to inhabited structures

\section{THE MACROSEISMIC SURVEY}

Also in this earthquake, the assessment of the site intensity $\left(\mathrm{I}_{\mathrm{S}}\right)$ was achieved by applying the MCS macroseismic scale, i.e., the scale adopted for the whole Italian macroseismic database (DBMI15). Indeed, as the European Macroseismic scale (EMS) [Grünthal 1998] requires the reconnaissance of the vulnerability class of each building, it is not easily or quickly applicable in the emergency survey of large earthquakes. For instance, in the case of the 2009 L'Aquila event $\left(M_{W} 6.3\right)$, the EMS survey of a limited number of damaged localities took a long time [Molin et al. 2010], with results published only two years later [Azzaro et al. 2011; Tertulliani et al. 2011]. In turn, as the MCS scale does not fully account for the vulnerability of each single building, it allows a more expeditious application during the survey, providing the information directly correlated to the damage level. We adopted the methodology proposed by Molin [2009], who considers the five damage levels (levels 1-5) included in almost all the macroseismic scales: light, moderate, severe, destruction, collapse. The evaluation of the percentages of these levels in a locality (i.e., 5\%, 25\%, 50\%, 75\% and 100\%) yield immediately the assessment of each MCS degree, as implicitly contained in the original scale [Sieberg 1930; e.g., in Galli et al. 2012].
The macrocosmic survey was carried out with the collaboration of the QUEST-INGV team, as in Galli et al. [2016]. It evidenced a huge variability of the building typologies within the same locality, with the presence of preexisting crumbling structures, well reinforced masonry buildings, overloaded roofs, old and new RC buildings. Sometime this variability makes the intensity assessment difficult or not just easily expressed by the usual uncertainness between two consecutive degrees (e.g., 6-7 MCS). Similarly to the macroseismic surveys of the earthquakes in 1997 (Umbria-Marche) [Camassi et al. 1997], 1998 (Calabria) [Galli et al. 2001], 2002 (Molise) [Galli and Molin 2004], 2009 (L'Aquila) [Galli et al. 2009], 2012 (Emilia) [Galli et al. 2012], even in 2016 we preferred to take more into account the effects surveyed within the historical centers. Indeed, only in very few circumstances, and always in the far field, light/moderate damage was observed more in the modern outskirts (e.g., on RC houses) than downtown (e.g., Ascoli Piceno, Cascia, Montefortino, Tolentino).

The highest IDD (>8 MCS degree) is markedly NNW-SSE elongated, paralleling the seismogenic structure (i.e., southern and northern tips of the Mount Vettore and Laga Mounts normal faults, respectively) [Galadini and Galli 2003] and entirely within the hangingwall block (Fig. 2). 


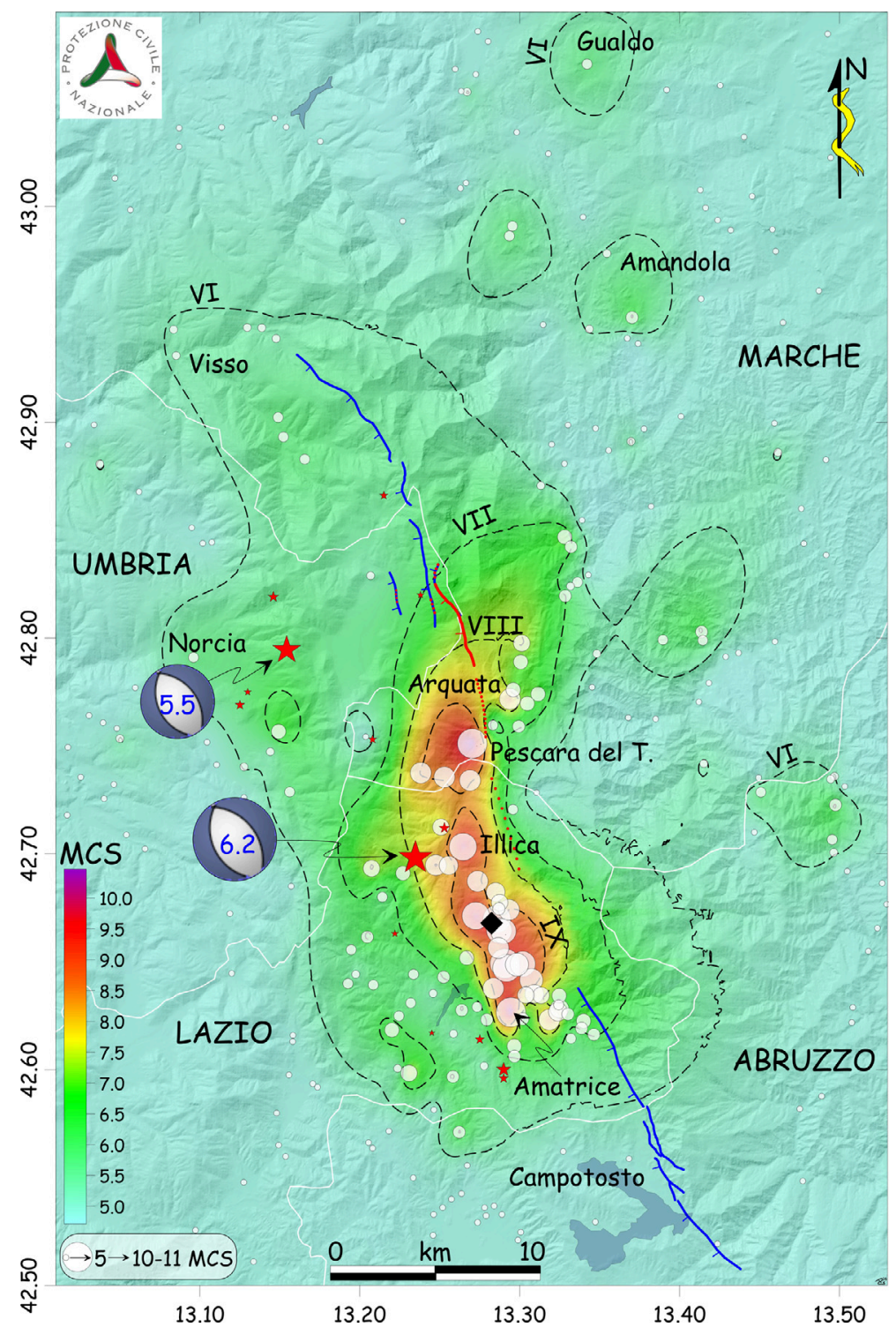

Figure 2. 2016 earthquake MCS intensity distribution. White circles, site intensities (dimension proportional to Is). Dotted line, isoseismals from 6 to 9 MCS. Cyan-to-red pattern indicates the areal distrubution of MCS intensity. Red stars, ML>4 events [ISIDe 2016]; black rhomb, macroseismic epicenter. The background is a 20-m-spaced DTM. Blue lines are the active fault segments of the Mount Vettore (north) and Laga Mounts (south) [Galadini and Galli 2003]. Red line (dotted where discontinuous) is the surface break/faulting of the 24 August 2016 earthquake.

Although the highest IDD are mostly southeast of the instrumental epicenter, light-tomoderate damage propagated preferentially toward northwest, i.e., along fault (Visso area). Moreover, sparse spots of intensity upswing exist also northward, in the far field, where we 
have found 6 MCS enclaves up to $40 \mathrm{~km}$ away from the epicenter (e.g., municipalities of Gualdo, Amandola, Montefortino), with also isolated heavy damage in the countryside.

The maximum intensities (Is $\geq 10$ MCS) fall in a 10-km-long belt between Illica and Amatrice, south of the instrumental epicenter, and at Pescara del Tronto, in the left bank of the Tronto River valley (Fig. 2). Almost all downtown of Amatrice (Fig. 3), together with Pescara del Tronto and Petrana (Fig. 1C-D) were razed to the ground (10-11 MCS), as well as Illica, Casale, Saletta and Crognale (10 MCS), all ville of Amatrice. Partly destroyed were also San Lorenzo e Flaviano, Sant'Angelo, Rio (9-10 MCS) and Sommati e Faizzone (9 MCS). Considering that a) some buildings in the outskirts of Amatrice did not collapse or were not destroyed, b) the impressive destruction of Pescara del Tronto was also due to gravity driven phenomena, and that c) only Petrana (31 buildings) was completely destroyed, we assign to this earthquake an epicentral intensity $\mathrm{I}_{0} 10 \mathrm{MCS}$ and a $\mathrm{I}_{\mathrm{MAX}} 10-11$.

The entire IDD was also processed through the program Boxer4 [Gasperini et al. 2010], in order to estimate other macroseismic parameters of the earthquake. The resulting epicenter is located $5 \mathrm{~km}$ to the southeast with respect to the instrumental one (Fig. 2), whereas the magnitude is $M_{W} 6.16 \pm 0.5$. The seismogenic source is a $\mathrm{N} 161^{\circ}$ striking box, $16 \mathrm{~km}$ long and $9 \mathrm{~km}$ wide centered on the obtained epicenter.

In the whole, besides the unquestionably elevated peak ground acceleration (0.45 PGA near Amatrice, rocky site) [RAN 2016], we can assess that the primary causes of the impressive destruction in the epicentral area are 1) the very high seismic vulnerability of all the old stone-masonry buildings, together with 2) the ineffective seismic retrofitting of many houses, and 3) the heavy concrete-roofs added diffusely in the second half of last century. Nevertheless, we also observed that the highest intensities were focused in the localities founded on the continental infilling deposits of the Amatrice basin, mainly clast-supported, coarse gravels passing upward to coarse sands and silty sands (i.e., fluvial and alluvial fan deposit, landslide accumulation, colluvia). This fact suggests that geological amplification phenomena contributed to the destruction of Amatrice and its ville.

\section{SEISMOTECTONIC IMPLICATIONS}

According to all the focal mechanisms calculated by different agencies (e.g., USGS, TDMT, QRCMT, CMT, GFZ, SLU, GCMT), the 24 August mainshock was generated by a normal fault trending $\mathrm{N} 140^{\circ}-\mathrm{N} 165^{\circ}$ and dipping $43^{\circ}$ $50^{\circ}$ (Figs. 2, 4). The seismic moment varies between 1.1 and $2.5^{*} 10^{\wedge} 25$ dyne ${ }^{*} \mathrm{~cm}$, with a resulting $M_{W}$ 6.0-6.2. The depth estimation varies between 4.4 and $12 \mathrm{~km}$, with a latest hypocentral re-localization at $8 \mathrm{~km}$ [GL-INGV, 2016]. The coseismic downthrown of the hangingwall has been depicted by several differential interferograms that were processed by several institutions (Fig. 3). In the whole, the area downthrown by $>5 \mathrm{~cm}$ is $\mathrm{N} 160^{\circ}$ elongated, $20-\mathrm{km}$ long and 6-km wide, suggesting thus the geometry and length of the causative fault(s) at depth. Indeed, there are two maximum subsidence zones, one centered near Illica $(22 \mathrm{~cm})$, and the other in the southern part of the Castelluccio Plain (18 cm; Fig. 4) [GSI 2016]. All these data fit both with 1) previous knowledge concerning active tectonics of the area, 2) field observation of 2016 coseismic surficial breaks and surface faulting, and 3) the highest IDD, and the resulting seismogenic box. 

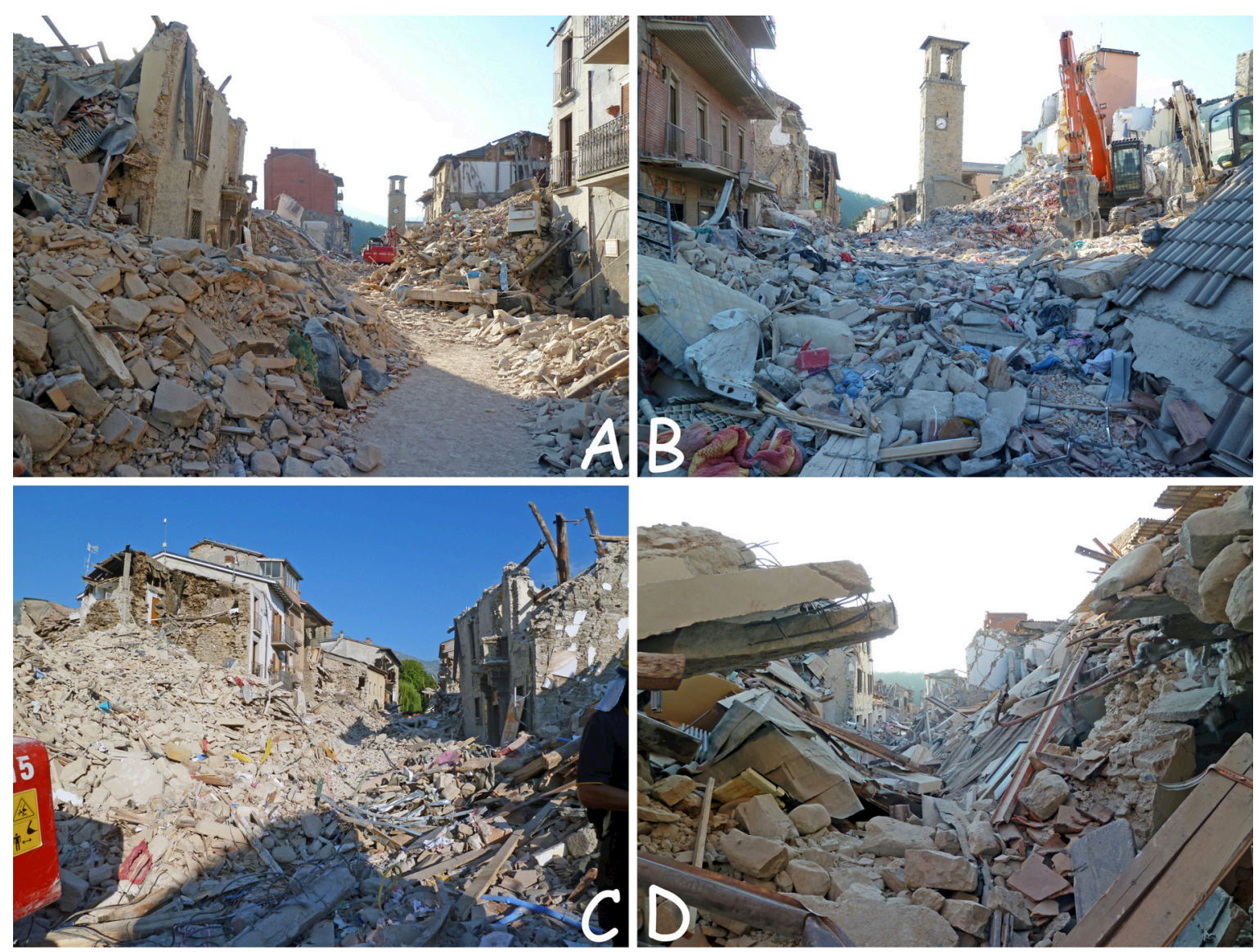

Figure 3. Views of the destroyed Amatrice downtown (10-11 MCS). A-C, Collapses of all the stone masonry buildings along Corso Umberto. Note that the only still-standing buildings are the Medieval tower $(A-B)$ - which survived also to the 1639 earthquake - and a 5-storeys RC apartment building ( $A$; this collapsed during the 30 October, $M_{w} 6.5$ earthquake). D, View of a road paralleling Corso Umberto, with almost complete destruction/collapse levels.

As far as point 1) is concerned, according to several authors, both the Mount Vettore fault and the Laga Mounts fault are active structures [Bachetti et al. 1990; Calamita and Pizzi 1992; Cello et al. 1997; Galadini and Galli 2000;
Galadini and Messina 2001; Boncio et al. 2004], and both generated large $\left(\mathrm{M}_{\mathrm{w}} \geq 6.5\right)$, unknown earthquakes in the Late Holocene [Galadini and Galli 2003]. 


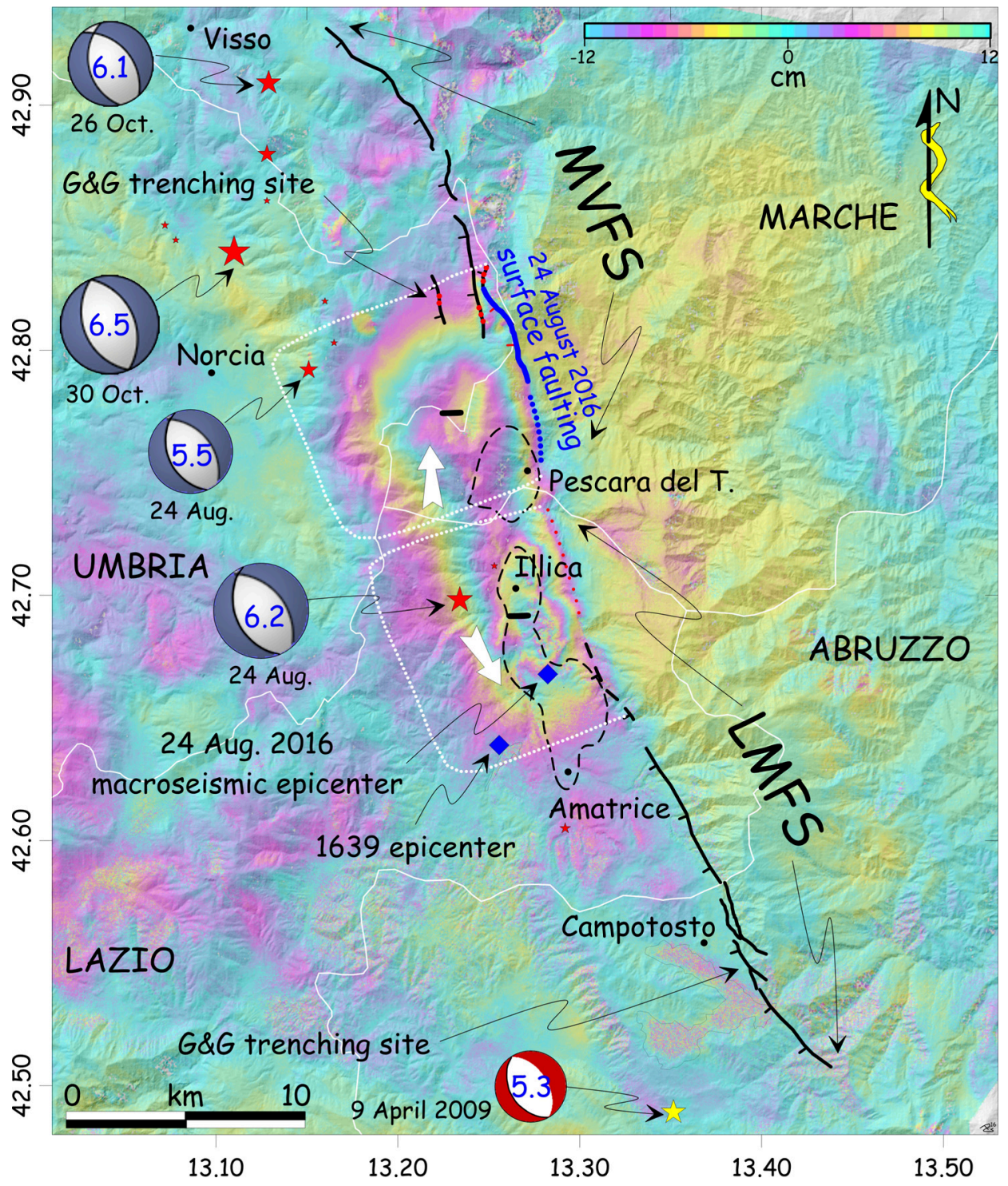

Figure 4. Interferogram processed by GSI [2016] using ALOS-2/PALSAR-2 data (displacement between satellite and ground in cm; date 25 May 25 and 31 August 2016. Descending flight direction). The two minus signs indicate about $20 \mathrm{~cm}$ of coseismic subsidence. Dashed line, 9 MCS isoseismal. Red stars, $M_{L}>4$ events [ISIDe 2016]; yellow star, 9 April 2009 event. MVFS, Mount Vettore fault system; LMFS, Laga Mounts fault system [GEG=Galadini and Galli 2003]. Blue line (blue/red dotted where discontinuous) is the surface break/faulting of the 24 August 2016 earthquake (white dotted line, fault area at depth). White arrows suggest the two rupture propagations of the $M_{w} 6.2,24$ August 2016 earthquake, one northward along the MVFS, the other southward along the LMFS. The two $M_{w} 6.1$ and $M_{w} 6.5$ occurred on 26 and 30 October, respectively, have been added. The $M_{w} 6.5$ event generated up to $2 \mathrm{~m}$ of surface faulting all along the MVFS. 
The most striking data concerning their recent activity and seismogenic potential were provided by three paleoseismological trenches excavated across one of the splays of the Mount Vettore fault and by one trench across the Laga Mounts fault [Galadini and Galli 2003] (Fig. 4). In particular, the most recent, $>0.5 \mathrm{~m}$ surface rupture event investigated on the Mount Vettore fault cut a reworked paleosol dated 3890$4300 \mathrm{BP}$, which was successively eroded and then sealed by other colluvia dated 50-265 AD and 240-480 AD, testifying thus the occurrence of a major earthquake between these ages.

About point 2), 2016 surface breaks and faulting formed continuously along the southernmost segment of the Vettore fault for a length of $6 \mathrm{~km}$ (Fig. 5), with further indication of sparse soil-fractures toward the Tronto River valley (Pescara del Tronto area) and along the foothill of the northern Laga Mounts. Leaving aside these discontinuous soil fractures, it is unquestionable that the observations made along the southern tip of the Vettore fault (namely, Cordone del Vettore-VettorettoCappella Spring trait) represent primary surface faulting. Indeed, this occurred mainly along the carbonate fault slickenside, producing both tension gashes (1-25 cm wide) and up to $0.3 \mathrm{~m}$ offset of the slope deposits in the hangingwall.

Considering all these information, it is possible to hypothesize that the 2016 earthquake enucleated at the northernmost tip of the Laga Mounts fault, immediately triggering the rupture of the southern segment of the Mount Vettore Fault. Hence, fault ruptures propagated southward on the Laga Mounts fault and northward on the Mount Vettore Fault, as confirmed by the inversion of both accelerometric and geodetic data [GL-INGV 2016]. Earthquake damage would be thus the summation of this bidirectional rupture along the two faults (Fig. 4), with the highest number of destroyed buildings in the hangingwall of the northern Laga Mounts fault segment (Amatrice basin), where most of the villages are clustered. In turn, the northward rupture along the Mount Vettore fault affected mainly a mountainous area, cutting also the ground surface, and razing to the ground "only" Pescara del Tronto, founded just at the extreme tip of the fault (see arrows in Fig. 4).

Therefore, we suggest that only the northern segment of the Laga Mounts fault had ruptured in 1639, generating an earthquake with effects similar to those observed on 24 August 2016 in the Amatrice basin. In 1639, the lacking rupture of the southern segment of the Mount Vettore fault in 1639 would explain the absence of damage north of Tronto River valley, as verified in Norcia. In turn, what Galadini and Galli [2003] have found trenching the basal Mount Vettore fault splay (Fig. 4) is not a rupture similar to the 2016 one (when only thin fractures were observed here), but the result of larger slip over the entire fault length, i.e., capable of rupturing with $>0.5 \mathrm{~m}$ offset also the secondary splays of the structure. This MW 6.5 earthquake [Galadini and Galli 2003] is still missing in the historical record, as well as the one that would be generated by the activation of the Laga Mounts fault segments located between the fault ruptures of 2016 and 2009 (9 April 2009, $\mathrm{M}_{\mathrm{W}}$ 5.3, Campotosto earthquake) [Cheloni et al. 2014] (Fig. 4). 


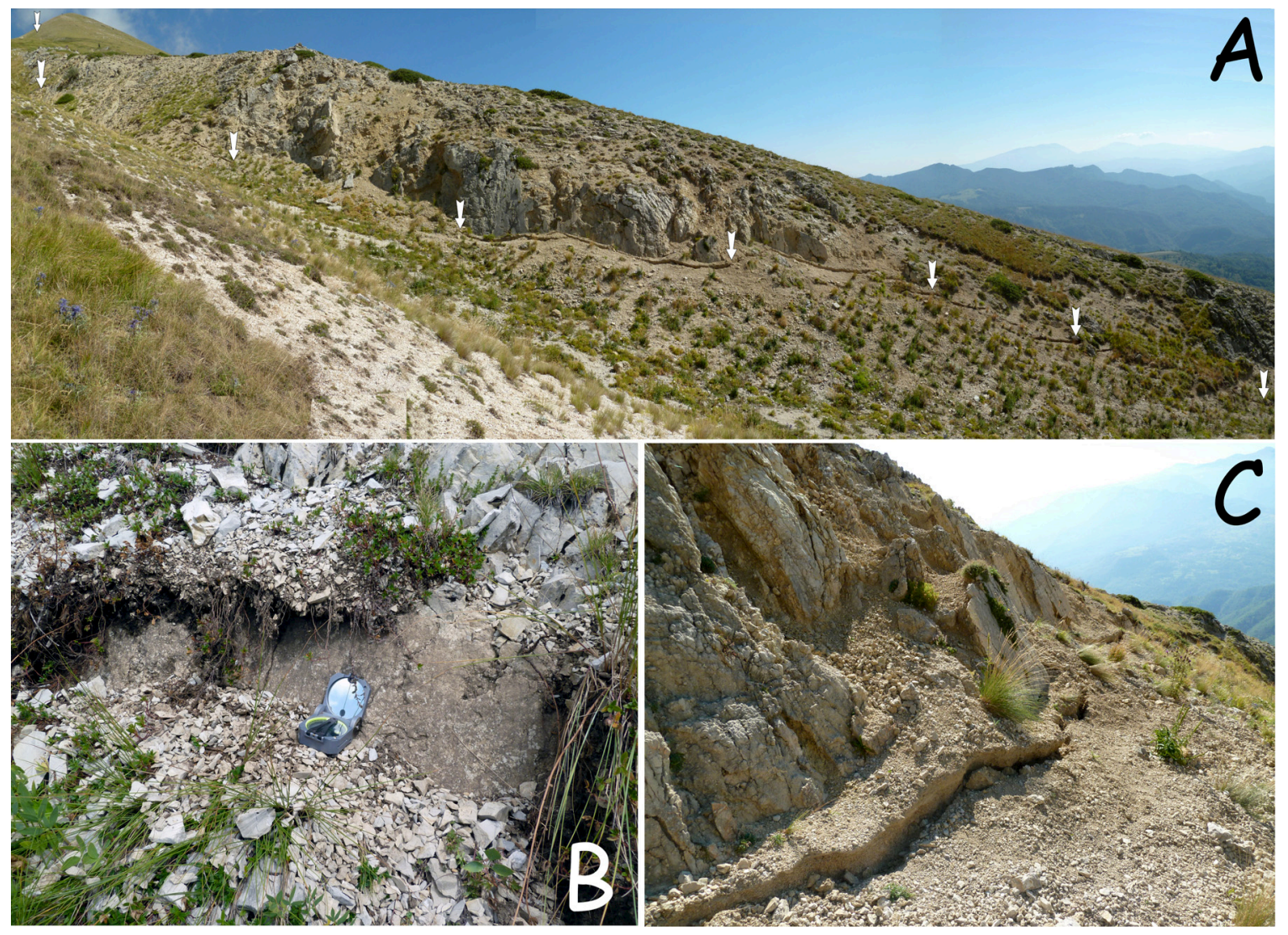

Figure 5. Pictures of the 24 August 2016 surface faulting along the Mount Vettore fault. A, southern slopes of the Mount Vettoretto segment (arrows point to the $10-30 \mathrm{~cm}$ step formed along the slickenside). B, faulting along the Cordone del Vettore segment. C, detail of the faulting in the mid of panel A. Surface faulting increased greatly after the 30 October earthquake (Mw 6.5), reaching also 2 of offset.

\section{CONCLUDING REMARKS}

We applied the MCS scale [Sieberg 1930] for the macroseismic survey of more than 300 localities belonging to 76 municipalities in the Provinces of Rieti (Lazio), Perugia (Umbria), Teramo and L'Aquila (Abruzzi), Ascoli Piceno, Macerata and Fermo (Marche) using the methodology proposed by Molin [2009]. Our resulting intensity datapoints distribution (IDD; Appendix 1) meets the primary purposes of the Civil Protection intervention (emergency planning and legislative provisions based on real damage levels), and can be directly com- pared to the historical earthquakes contained in the Italian seismic database.

We estimated an epicentral intensity of I0 10 MCS (IMAX 10-11 MCS), with a macroseismic epicenter located $5 \mathrm{~km}$ southeast to the instrumental one. In turn, the magnitude is $\mathrm{M}_{\mathrm{W}}$ $6.16 \pm 0.5$, which is a value very close to the instrumental one $\left(\mathrm{M}_{\mathrm{W}}\right.$ 6.2) [RCMT 2016], with a source $16 \mathrm{~km}$ long and $9 \mathrm{~km}$ wide, striking $\mathrm{N} 161^{\circ}$. This fault azimuth fits well the strike of the supposed causative faults, i.e., two different segments of the the Laga Mounts-Mount Vettore faults. 
Geological, geodetical and seismological data suggest a bidirectional rupture propagation from the instrumental hypocenter: southward along the northern segment of the Laga Mounts fault, and northward along the southern segment of the Mount Vettore fault ${ }^{1}$, where extensive evidence of surface faulting were also observed. This implies that the earthquake that hit Amatrice and its ville in $1639\left(\mathrm{M}_{\mathrm{W}}\right.$ 6.0) might be a twin of the rupture of the southern fault strand in 2016, i.e., subtracting the effect of the northern fault rupture. In turn, to date, we are still missing the earthquakes that can be caused by the entire activation of the Mount Vettore fault, and by the main segments of the Laga Mounts fault, i.e., those outcropping between the ruptures of the 2016 segment to the north, and the smaller $2009\left(\mathrm{M}_{\mathrm{W}}\right.$ 5.3) segment to the south.

\section{ACKNOWLEDGMENTS}

We are grateful to Caterina Iambrenghi for making available the unpublished data on the effects of the 1639 earthquake in Norcia. We are also grateful to Ina Cecić who revised the original manuscript, providing useful criticisms and corrections.

\section{APPENDIXES}

In the appendix section, the PDF file PQ04102016 contains the MCS intensities of the 24 August earthquake.

\section{REFERENCES}

\footnotetext{
${ }^{1}$ Actually, this happened on 30 October 2016, when the $\mathrm{Mw} 6.5$ earthquake ruptured the whole Mount Vettore fault system, with surface faulting all along the MVFS and offset up to $2 \mathrm{~m}$. The survey of macroseismic effects of this earthquake is still in progress at the moment.
}

ASAQ [Archivio di Stato dell'Aquila], 17 ${ }^{\text {th }}$ cent. Notai aquilani, Agostino They [di Amatrice], b. 741, fasc. IX, c. 373.

ASCN [Archivio Storico Comunale di Norcia], 17th cent. Consigli e Riformanze, 104, cc. 130v131.

Azzaro, R., M.S. Barbani, S. D'amico and A. Mostaccio (2011). The L'Aquila 2009 earthquake: an application of the European Macroseismic Scale to the damage survey in the epicentral area, BGTA, 52, 561-581.

Bachetti, C., A.M. Blumetti, G. Calderoni and M. Ridolfi (1990). Attività neotettonica e paleosismica del settore meridionale dei Monti della Laga, Rendiconti Società Geologica Italiana, 13, 9-16.

Boncio, P., G. Lavecchia, G. Milana, and B. Rozzi (2004). Seismogenesis in Central Apennines, Italy: an integrated analysis of minor earthquake sequences and structural data in the Amatrice-Campotosto area. Annals of Geophysics, 47 (6), 1723-1742.

Calamita, F. and A. Pizzi (1992). Tettonica quaternaria nella dorsale appenninica umbromarchigiana e bacini intrappenninici associati, Studi Geol. Cam., 1, 17-25.

Camassi, R., P. Galli, D. Molin, G. Monachesi and G. Morelli (1997). Rilievo macrosismico preliminare del terremoto Umbro-Marchigiano di Settembre-Ottobre 1997. Ing. Sism., 14 (3), 22-26.

Castelli, V., F. Galadini, P. Galli, D. Molin and M. Stucchi (2002). Caratteristiche sismogenetiche della sorgente della Laga e relazione con il terremoto del 1639, Riassunti del $21^{\circ}$ Convegno nazionale del GNGTS, 19-21 novembre 2002, Roma, 13-16.

Cello, G., S. Mazzoli, E. Tondi and E. Turco (1997). Active tectonics in the Central Apennines and possible implications for seismic hazard analysis in peninsular Italy, Tectonophysics, $272,43-68$. 
Cheloni, D., R. Giuliani, E. D'Anastasio, S. Atzori, R.J. Walters, L. Bonci, N. D'Agostino, M. Mattone, S. Calcaterra, P. Gambino, F. Deninno, R. Maseroli and G. Stefanelli (2014). Coseismic and post-seismic slip of the 2009 L'Aquila (central Italy) Mw 6.3 earthquake and implications for seismic potential along the Campotosto fault from joint inversion of highprecision levelling, InSAR and GPS data. Tectonophysics, 622, 168-185.

Galadini, F. and P. Galli (2000). Active tectonics in the Central Apennines (Italy) - input data for seismic hazard assessment, Nat. Hazards, 22, 225-270.

Galadini, F. and P. Messina (2001). PlioQuaternary changes of the normal fault architecture in the Central Apennines (Italy), Geod. Acta, 14, 321-344.

Galadini, F. and P. Galli (2003). Paleoseismology of silent faults in the central Apennines (Italy): the Mt. Vettore and Laga Mts. Faults, Annals of Geophysics, 46, 815-836.

Galli, P., D. Molin, R. Camassi and V. Castelli (2001). Il terremoto del 9 settembre 1988 nel quadro della sismicità storica del confine calabro-lucano. Possibili implicazioni sismotettoniche. Il Quaternario. Italian Journal of Quaternary Sciences, 14 (1), 31-40.

Galli, P. and D. Molin (2004). Macroseismic Survey of the 2002 Molise, Italy, Earthquake and Historical Seismicity of San Giuliano di Puglia. Earthquake Spectra, 20 (S1), S39-S52.

Galli, P., R. Camassi, R. Azzaro, F. Bernardini, S. Castenetto, D. Molin, E. Peronace, A. Rossi, M. Vecchi and A. Tertulliani (2009). Il terremoto aquilano del 6 aprile 2009: rilievo macrosismico, effetti di superficie ed implicazioni sismotettoniche, Il Quaternario, Italian Journal of Quaternary Sciences, 22, 235-246.

Galli, P., S. Castenetto and E. Peronace (2012). May 2012 Emilia Earthquakes (Mw 6, Northern Italy): Macroseismic effects distribution and seismotectonic implications. Alpine and Mediterranean Quaternary 25(2), 105-121.

Galli, P., E. Peronace and A. Tertulliani (2016). Rapporto sugli effetti macrosismici del terremoto del 24 agosto 2016 di Amatrice in scala MCS. Roma, Rapporto congiunto DPC, CNRIGAG, 15 pp.; doi:10.5281/zenodo.161323.

Gasperini, P., G. Vannucci, D. Tripone and E. Boschi (2010). The location and sizing of historical earthquakes using the attenuation of macroseismic intensity with distance, B. Seismol. Soc. Am., 100, 2035-2066; doi: 10.1785/0120090330.

GL-INGV [Gruppo di Lavoro INGV sul terremoto di Amatrice] 2016. Secondo rapporto di sintesi sul Terremoto di Amatrice Ml 6.0 del 24 Agosto 2016 (Italia Centrale), doi: 10.5281 / zenodo. 154400 .

Grünthal, G. (eds) (1998). European Macroseismic Scale 1998. European Seismological Commission, Subcommission on Engineering Seismology, Working Group Macroseismic Scales, Cahiers du Centre Européen de Géodynamique et de Séismologie, 15, pp. 99. Luxemburg.

GSI [Geospatial Information Authority of Japan] 2016. The 2016 Central Italy Earthquake: Crustal deformation detected by ALOS-2 data, http:/ / www.gsi.go.jp/ cais/topic160826index-e.html.

ISIDe working group (2016). version 1.0, DOI: 10.13127/ ISIDe.

Locati, M., R. Camassi, A. Rovida, E. Ercolani, F. Bernardini, V. Castelli, C.H. Caracciolo, A. Tertulliani, A. Rossi, R. Azzaro, S. D'Amico, S. Conte and E. Rocchetti (2016). DBMI15, the 2015 version of the Italian Macroseismic Database, Istituto Nazionale di Geofisica e Vulcanologia, doi:http: / / doi.org/10.6092/ INGV.IT-DBMI15.

Molin, D. (2009). Rilievo macrosismico in emergenza. Rapporto interno del Dipartimento della Protezione Civile, Ufficio Valutazione, 
prevenzione e mitigazione del rischio sismico, $13 \mathrm{pp}$.

Molin, D., E. Peronace, S. Castenetto and P. Galli (2010). Terremoto aquilano del 6 aprile 2009: rilievo dei danni a Sant'Eusanio Forconese e stima dell'intensità macrosismica secondo la scala EMS-98. Atti del $29^{\circ}$ Convegno Nazionale GNGTS, 77-79, 26-28 ottobre 2010, Prato.

RAN (2016). Rete Accelerometrica Nazionale RAN Download. Dipartimento della Protezione Civile, Presidenza del Consiglio dei Ministri.

http:/ / ran.protezionecivile.it/IT/index.php

RCMT (2016). European-Mediterranean RCMT Catalog, web page: http:/ / www.bo.ingv.it/ RCMT /

Rovida, A., M. Locati, R. Camassi, B. Lolli and P. Gasperini (eds) (2016). CPTI15, the 2015 version of the Parametric Catalogue of Italian Earthquakes. Istituto Nazionale di Geofisica e Vulcanologia.

doi:http: / / doi.org/10.6092 / INGV.IT-CPTI15

Sieberg, A. (1930). Geologie der Erdbeben. Handboch der Geophysic, 2, 4, 552-554 [Tabb. 100, 101, 102, 103], Berlin.

Tertulliani A., L. Arcoraci, M. Berardi, F. Bernardini, R. Camassi, C. Castellano, S. Del Mese, E. Ercolani, L. Graziani, I. Leschiutta, A. Rossi and M. Vecchi (2011). An application of
EMS98 in a medium-sized city: The case of L'Aquila (Central Italy) after the April 6, 2009 Mw 6.3 earthquake, Bull. Eartquake Eng., 9, 67-80.

Tiberi, C. (1639). Nuova e vera relatione del terribile, e spaventoso terremoto successo nella città della Matrice, e suo stato, con patimento ancora di Accumulo, e luoghi circonvicini, sotto li 7 del presente mese di Ottobre 1639, con la morte compassionevole di molte persone, la perdita di Bestiame d'ogni sorte, e con tutto il danno seguito fino al corrente giorno. Con ogni diligenza, e certezza descritta da Carlo Tiberii Romano, per memoria d'un caso così miserando, e lagrimevole. Roma, 3 pp.

Uria De Llanos, A. (1703). Relazione overo itinerario fatto dall'auditore D. Alfonso Uria De Llanos per riconoscere li danni causati dalli passati Terremoti seguiti li 14 Gennaro e 2 Febraro MDCCIII con il numero de' Morti, e Feriti nella provincia dell'Aquila, e tutti li luoghi circonvicini per darne di essi distinta notizia al Signor Vice Ré di Napoli. Stamperia Gaetano Zenobj, Roma. 